\title{
Hypoxia-induced leptin production in human trophoblasts does not protect from apoptosis
}

Udo Meißner, Robert Spranger, Manfed Lehner, Ida Allabauer, Wolfgang Rascher and Jörg Dötsch

Department of Pediatrics, University of Erlangen-Nürnberg, Loschgestrasse 15, Erlangen 91054, Germany

(Correspondence should be addressed to (U Meißner; Email: udo.meissner@kinder.imed.uni-erlangen.de)

(U Meißner and R Spranger contributed equally to this work)

\begin{abstract}
Objective: The $o b$-gene product, leptin, is an important regulator of placental and fetal development during pregnancy. Leptin, being induced by hypoxia in the placenta, is a known pro-apoptotic molecule in adipose tissue but is also known to inhibit apoptosis in other tissues like neuroblastoma cells. Based on these findings, we investigated if leptin has a pro- or anti-apoptotic effect on a trophoblastic cell line (JAr cells) in the presence or absence of oxygen.

Methods and results: Measurement of leptin in the supernatant by using ELISA showed hypoxiainduced leptin production in JAr cells in vitro. This could be confirmed by a leptin-specific RT-PCR. By analyzing leptin and/or hypoxia exposed cells with FACS cytometry we found that JAr cells can cope with hypoxia down to oxygen tensions of $1 \%$. At this level, only a small number of cells underwent apoptosis. Interestingly, leptin added to the culture medium in high concentrations was not able to interfere with the rate of proliferation or apoptosis in these cells independent of the oxygen tension. Finally, an anti-caspase- 3 and anti-caspase- 9 Western blot was performed. Again, no difference in the expression of caspase- 3 and -9 under the conditions tested was seen.

Conclusions: These results show that leptin, produced by placental cells after hypoxia in vitro, has no influence on the rate of proliferation of these cells. Furthermore, it does not influence apoptotic pathways in the trophoblastic cell line tested under hypoxic and non-hypoxic conditions.
\end{abstract}

European Journal of Endocrinology 153 455-461

\section{Introduction}

The discovery of the adipose-derived hormone, leptin, has generated increased interest in its involvement in the regulation of feeding by interacting with central nervous structures. There is increasing evidence that leptin has systemic effects apart from those related to energy homeostasis (1). These include the regulation of neuroendocrine and immune function, modulation of the cell cycle, and a role in fetal development or tissue repair $(2-5)$. Mammalian cells have multiple responses to decreased oxygen tension. By far the most common reaction to low or zero oxygen concentrations is cell death through apoptosis. Apoptotic signaling during oxygen deprivation occurs through the release of cytochrome $\mathrm{c}$ and the activation of caspase- 9 mediated by Bcl-2 family members such as Bax or Bak (reviewed in detail in (6)). Trophoblasts are responsible for the maternalfetal exchange of gas, nutrients and waste products. Therefore, placental apoptosis is a key cellular interface in the control of placental homeostasis (7). Several authors have provided evidence for a connection between pathological states during pregnancy (e.g. preeclampsia) and increased placental apoptosis (8-10). Leptin plays a dual role regarding apoptosis as it can act either as a pro- or an antiapoptotic messenger. First, leptin was reported to be responsible for the induction of lipolysis. Thus, this is an effect mediated through apoptosis of the adipose tissue (11). In contrast, Fujita et al. demonstrated that leptin in fasted mice is able to prevent the apoptotic reduction of lymphocyte numbers in steroid-injected mice via a $b c l-x L$-dependent mechanism (12). This anti-apoptotic effect of leptin is in line with evidence that the hormone protects SK-N-SH-SY5Y neuroblastoma cells from apoptosis in serum-free medium by a STAT/JAK-dependent down regulation of caspase-10 and tumor necrosis factor-related apoptosis-inducing ligand (TRAIL) (13). It is well known that leptin contributes to a physiological pregnancy by regulation of implantation, energy balance of placenta and conceptus, as well as an angiogenic factor (14-16). During pregnancy, leptin expression undergoes dramatic changes in maternal plasma in parallel with the rising of cytokine levels during the first trimester (17) returning to normal 
levels after delivery (18). The production of placental leptin is reported to be increased by interleukin- $1 \alpha, 17 \beta$-estradiol and hypoxia (19-21). Preeclampsia is a disorder associated with maternal hypertension, reduced placental blood flow and placental hypoxia (22). Elevated concentrations of leptin are found when comparing sera and placental tissues from women with preeclampsia with sera of mothers with uncomplicated pregnancies (23-25). Apart from the placenta, many peripheral tissues including heart, liver, kidneys and muscle react to hypoxia with an increased transcription of leptin which is mediated by a hypoxia-inducible factor$1 \alpha$ (HIF-1 $\alpha)$-dependent mechanism (26-32).

Based on these findings and the dual role of leptin as a pro- or anti-proliferative factor, we were interested in how leptin could influence hypoxia-induced cell death in JAr cells, a trophoblastic cell line. Therefore, we set out to ask the following questions. (i) Are JAr cells expressing the functional variants of the leptin receptor? (ii) Is hypoxia able to induce leptin production in JAr cells? (iii) How does hypoxia influence the viability and death of the cells? (iv) Is the exposure to hypoxia in vitro followed by an increased rate of apoptosis? (v) How does leptin interact with $\beta$-human chorionic gonadotropin ( $\beta$-hCG) secretion, and the proliferation and apoptosis of these cell lines under normoxic and hypoxic conditions?

\section{Materials and methods}

\section{Cell culture and reagents}

JAr cells were purchased from DSMZ (Braunschweig, Germany), and cultured in D-MEM:F-12 (purchased from Gibco-BRL, Eggenstein, Germany) supplemented with $10 \% \mathrm{FCS}, 100 \mu \mathrm{g} / \mathrm{ml}$ penicillin, and $1000 \mathrm{U} / \mathrm{ml}$ streptomycin (purchased from Clonetech, BD Biosciences, Heidelberg, Germany), in the presence or absence of different stimuli and chemicals as indicated. Cells were cultured under normoxic conditions at $37^{\circ} \mathrm{C}$ under a humidified atmosphere containing 5\% $\mathrm{CO}_{2}$ unless stated otherwise. Leptin was purchased from R\&D Systems (Minneapolis, MN, USA).

\section{Treatment of cells}

Before plating, cells were trypsinized and washed twice in cold PBS followed by resuspension in the respective culture medium. They were plated into 6-well plates and stimulated with various concentrations of leptin $(1.0 \mu \mathrm{g} / \mathrm{ml}$ to $0.25 \mu \mathrm{g} / \mathrm{ml})$ or incubated under hypoxic conditions $\left(1 \%\right.$ or $\left.5 \% \mathrm{O}_{2}\right)$ for the time period indicated.

\section{RNA isolation, reverse transcription- polymerase chain reaction (RT-PCR)}

Total RNA was isolated from $5 \times 10^{5} \mathrm{JAr}$ cells using TRIzol (Gibco-BRL, Life Technologies). After DNase treatment, $1.5 \mu \mathrm{g}$ RNA were transcribed into cDNA using M-MLV-RT (Promega, Mannheim, Germany) and Oligo(dT). DNase treatment and cDNA synthesis were carried out according to the manufacturer's recommendations. The cDNA expression level was quantified by conventional PCR analysis. A $25 \mu$ l reaction mixture contained the following ingredients: $2 \mu \mathrm{l}$ cDNA, $1 \times$ Taq reaction buffer, $2.5 \mathrm{mmol} / \mathrm{l} \mathrm{MgCl}_{2}, 1 \mathrm{mmol} / \mathrm{l}$ $\mathrm{dNTP}, 0.25 \mu \mathrm{mol} / \mathrm{l}$ forward primer, $0.25 \mu \mathrm{mol} / \mathrm{l}$ reverse primer, and $1 \mathrm{U}$ Taq Polymerase (Promega). For amplification of the two different isoforms of the leptin receptor we used the following primers: short leptin receptor (ObRs): sense 5'-GTAAGAGGCTAGATGGACTGGGATAT-3', ObRs antisense 5'-ATTCTCCAAAATTCAGGTCCTCTCA-3'; long leptin receptor sense (ObRI): 5'-AGGCTGAGGGTACTGAGGTAACC-3', ObRI antisense 5'GATCAGCGTGGCGTATTTAAC A-3'.

\section{Real-time PCR}

For analyzing the gene expression (mRNA) of leptin and of the hypoxanthine-guanine phosphoribosyltransferase (HPRT), as well as of porphobilinogen deaminase (PBGD) as housekeeping genes, we used the primers as previously described (21). All assays were performed using a quantitative real-time polymerase chain reaction (TaqMan PCR, PerkinElmer Life Sciences Inc. Boston, MA, USA). All calculations were based on the ${ }^{\Delta \Delta} \mathrm{Ct}-$ method as described in detail elsewhere (26).

\section{Leptin ELISA}

Concentrations of leptin in the culture supernatants were measured by using the Human Leptin DuoSet ELISA Development System (R\&D Systems) following the recommendations of the manufacturer.

\section{$\beta$-hCG ELISA}

Concentrations of $\beta$-hCG in the culture supernatants were measured by using the DRG- $\beta$-hCG-ELISA kit (DRG Instruments, Marburg, Germany) following the recommendations of the manufacturer.

\section{Flow cytometry and annexin-V/propidium iodide apoptosis assay}

Apoptotic cell detection was performed using fluoresceinisothiocyanate (FITC)-conjugated annexin-V-Fluos (Responsif, Erlangen, Germany) and propidium iodide (Sigma, Deisenhofen, Germany), following the manufacturer's instruction. Briefly, $10^{6}$ cells were collected for each condition, trypsinized, washed with cold PBS and resuspended in $100 \mu \mathrm{l}$ incubation buffer (10 mmol/l HEPES/NaOH, pH 7.4, $140 \mathrm{mmol} / \mathrm{l} \mathrm{NaCl}$, $3.3 \mathrm{mmol} / \mathrm{l} \mathrm{CaCl}_{2}$ ) containing $2 \mu \mathrm{l}$ annexin V-Fluos and $2 \mu \mathrm{l}$ propidium iodide (PI). After $15 \mathrm{~min}$ of incubation in the dark at room temperature, $400 \mu \mathrm{l}$ cold 
incubation buffer were added and cells were analyzed by flow cytometry (FACSCalibur, Becton-Dickinson, Heidelberg, Germany), using $488 \mathrm{~nm}$ excitation and band pass filters of $530 / 30 \mathrm{~nm}$ (for FITC detection) and 585/42 nm (for PI detection). For each cell type, appropriate electronic compensation of the instrument was performed to avoid overlapping of the two emission spectra. Data analyses were performed with Cell Quest software (Becton-Dickinson). Cells were counted using CALTAG Counting Beads (Caltag Laboratories, Burlingame, CA, USA) as recommended by the manufacturer.

\section{SDS-PAGE and Western blot}

Cells were lysed in buffer containing Igepal-630 and sodium desoxycholate as detergents (all chemicals purchased from Sigma). Equal amounts of protein were separated by $12 \%$ SDS-PAGE, blotted to a Protran nitrocellulose membrane (Schleicher \& Schuell, Dassel, Germany), and detected with a rabbit anti-human-caspase-3 or -9 polyclonal antiserum (Cell Signaling Technology/Upstate Biotech, Lake Placid, NY, USA) followed by a visualization using a horseradish peroxidase-conjugated goat anti-rabbit IgG (Cell Signaling Technology) and ECL Plus on Kodak BioMax (both purchased from Amersham Pharmacia Biotech, Freiburg, Germany).

\section{Statistical analysis}

If not otherwise stated, all values are given as means \pm standard errors. A Kruskal-Wallis one-way ANOVA was used to calculate the differences between the different groups (control vs hypoxia vs leptin vs hypoxia + leptin). Given a significant $P$ value $(P<0.05)$, a Dunn's multiple comparison followed the ANOVA test. All calculations were performed using GraphPad Prism 4.0 (GraphPad Software, San Diego, CA, USA).

\section{Results}

In this study we tested the hypothesis that leptin influences hypoxia-induced apoptosis in trophoblasts and human kidney cells. We used the human choriocarcinoma cell line JAr, which has previously been proved to be a useful model for the study of placenta biology for in vitro assays (33). When testing these cells for the expression of the different leptin receptor isoforms by RT-PCR, two types, the short and the long functional variants of the leptin receptor, could be detected (Fig. 1). One aim was to study to what extent endogenous leptin is produced by these cells after exposure to hypoxia. Therefore, JAr cells have been tested on their ability to produce leptin after incubation under various hypoxic conditions. When incubating JAr cells under hypoxic conditions $\left(1 \% \mathrm{O}_{2}\right.$ for 6 to $\left.48 \mathrm{~h}\right)$ they reacted with a significant increase in leptin-specific mRNA. The amount of leptin-specific mRNA rose up to

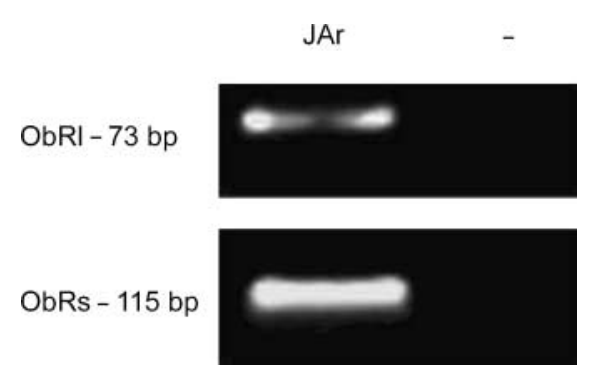

Figure 1 Expression profiles of leptin receptor isoforms. JAr cells express both isoforms (long, ObRI variant and short, ObRs variant) of the leptin receptor. $\mathrm{H}_{2} \mathrm{O}$ as template served as a negative control (-).

10-fold when comparing hypoxic cells to untreated controls (Fig. 2A). The augmented leptin mRNA was followed by a significant increase of the hormone in the culture supernatants of the stimulated cells throughout the whole period studied. All specimens taken from hypoxic cell cultures had more leptin than those of untreated, normoxic controls (Fig. 2B). To analyze the changes in the viability of the cells and the rate of apoptosis, cells were subjected to flow cytometry using the annexin V/PI method to divide them into apoptotic, viable and dead cells. By using the annexin $\mathrm{V}$ staining, the cells can be analyzed regarding their rate of apoptosis prior to morphological changes associated with apoptosis. Cells negative for the annexin $\mathrm{V}$ and the PI dye were regarded as viable cells (Fig. 3, R2). In contrast, cells staining positive for annexin $\mathrm{V}$ and the non-vital dye PI were interpreted as being dead (Fig. 3, R3). In between, two groups of intact cells could be discriminated by this method: (a) the early apoptotic (EA) cells are annexin $\mathrm{V}$ positive but negative for PI (Fig. 3, R4), and (b) the late apoptotic (LA) cells (Fig. 3, R5) that are positive for both dyes, but could be distinguished clearly from the highly PIpositive (dead) cells. We established this method, which had previously been described for leukocytes, and used it for the analysis of trophoblasts. With the following assays we were able to get an insight into the effects that leptin might exert on apoptosis and proliferation in the presence or absence of oxygen. JAr cells were incubated for $24 \mathrm{~h}$ or $48 \mathrm{~h}$ under normoxic or hypoxic ( $1 \%$ or $5 \%$ oxygen) conditions, in the presence of leptin $(250 \mathrm{ng} / \mathrm{ml}$ to $1.0 \mu \mathrm{g} / \mathrm{ml})$ or in the presence of a combination of leptin and hypoxia. When focusing on the effects after $24 \mathrm{~h}$, no significant effect of either leptin or hypoxia on vitality or apoptosis could be detected by flow cytometry. The results obtained from assays using $1.0 \mu \mathrm{g} / \mathrm{ml}$ leptin and $1 \%$ $\mathrm{O}_{2}$ are depicted in Table 1. These effects were independent of the dose of leptin and the hypoxic conditions, as reducing the leptin concentration to 500 or $250 \mathrm{ng} / \mathrm{ml}$ (data not shown) had no effect. After 48 h, a significant decrease in the number of annexin $\mathrm{V}$ and PI double negative (vital) cells could be measured in JAr cells. The percentage of dead JAr cells was about three 

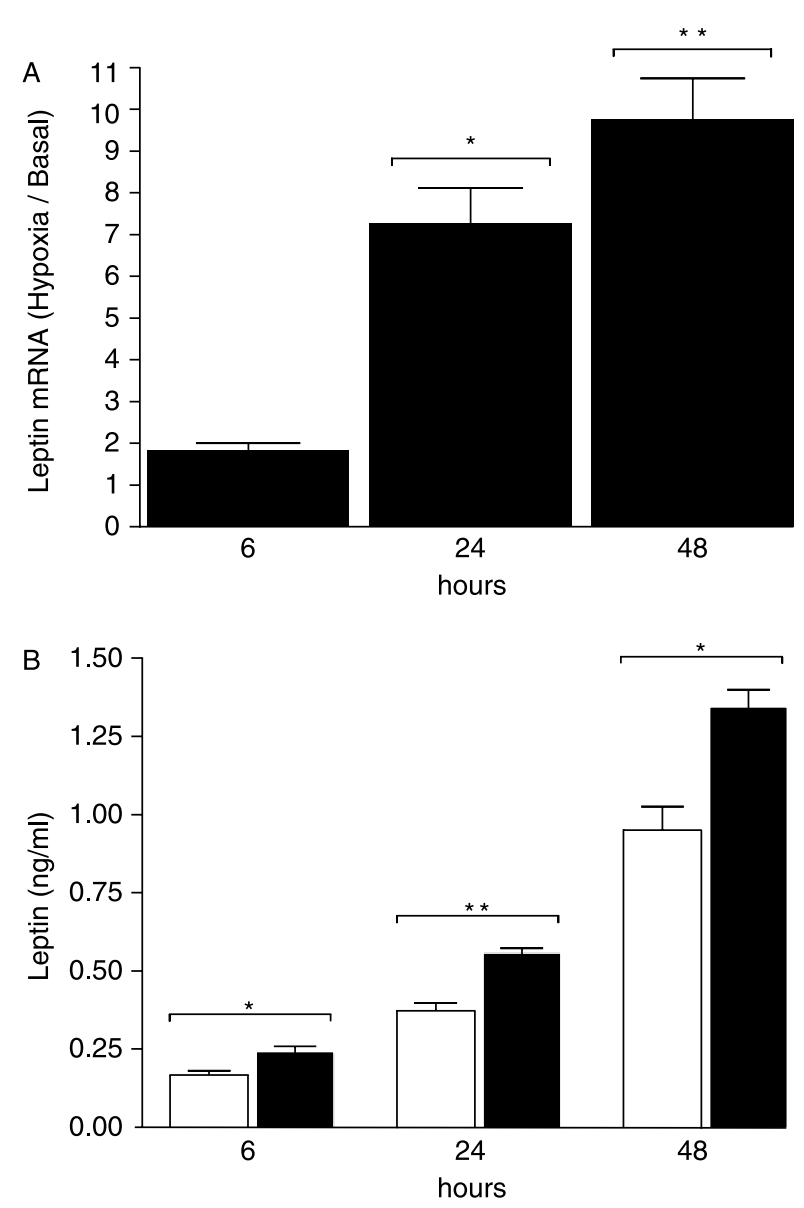

Figure 2 Elevated concentrations of leptin-specific mRNA and protein in lysates and supernatants of hypoxia-incubated trophoblastic cells. JAr cells were incubated under hypoxic conditions at an oxygen tension of $1 \% \mathrm{O}_{2}$ for 6 to $48 \mathrm{~h}$. Cells incubated without a stimulus under normoxic conditions were used as controls. After the period indicated, cells were subjected to cDNA synthesis, and supernatants were collected for ELISA analysis. The amount of leptin mRNA, relative to the levels of two housekeeping genes, was measured to calculate the relative change in induction of leptin mRNA; both housekeeping genes gave similar results. Data normalized to PBGD as the housekeeping gene are displayed as fold induction compared with unstimulated controls (A). Leptin protein in supernatants was measured using a specific two-site ELISA with a standard of known concentration (B). Open bars, normoxic cells; solid bars, hypoxic cells. The data represent the mean of 3 identical experiments. ${ }^{*} P<0.05,{ }^{*} P<0.01$ compared with normoxic controls.

times higher than those of the normoxic controls (Table 1). Exposure of JAr cells to hypoxia for $48 \mathrm{~h}$ initiated a significant increase in early and late apoptotic cells compared with normoxic controls. Thus, the addition of leptin to these cells had no effect either on the percentage of apoptotic cells or on the differentiation between EA and LA (Table 1). In the following steps, we tested if the addition of leptin (at high concentrations of $1 \mu \mathrm{g} / \mathrm{ml}$ to $250 \mathrm{ng} / \mathrm{ml}$ ) or incubation under hypoxic conditions had a significant effect on the proliferation of the two different cell lines as determined by counting the cells after the incubation period using flow cytometry. A small (but non-significant) increase in absolute cell numbers could be detected when leptin was added to the cells for $24 \mathrm{~h}$; hypoxic conditions influenced proliferation in a negative manner. This effect could not be overruled by the addition of leptin to the JAr cells (Fig. 4). To determine if the expression of caspases is influenced by exposure to hypoxia in the presence or absence of leptin, lysates from JAr cells were subjected to Western blot analysis. No difference in the expression of caspase- 3 and caspase- 9 could be detected when the cells were incubated for $24 \mathrm{~h}$ under $1 \%$ oxygen with or without $1 \mu \mathrm{g} / \mathrm{ml}$ leptin (Fig. 5).

\section{Discussion}

Human embryogenesis takes place in an hypoxic environment because the trophoblast shell prevents the entry of oxygen via maternal blood. Throughout gestation the oxygen tension rises (34). As anerobic conditions are a common feature in the placenta, at least within the first trimester, it is clear that differentiation of placental cells and the maintenance of the feto-placental unit is dependent on hypoxia-induced signals (35, 36). Thus, a variety of pathophysiological conditions during pregnancy are accompanied by hypoxia (10, 34,37 ). It was shown by Esterman et al. that in vitro cultures of trophoblasts can survive extreme hypoxia and that they react rapidly to restitution of normal oxygen tension by readopting their reduced metabolism and cell cycle (38). This is in line with the data from the present study. Here, the trophoblastic choriocarcinoma cell line, JAr, showed a better survival following hypoxia than 293HEK cells, an embryonic kidney cell line (data not shown). Programmed cell death plays a pivotal role in maintaining placental development and function throughout gestation $(7,35)$. But even here, the border between 'good' and 'bad' apoptosis has to be drawn tightly as it is known that preeclampsia is linked to an increased rate of apoptotic death within trophoblasts $(8-10)$. We tested if apoptosis could be induced in JAr cells by incubating the cells under hypoxic conditions $\left(1 \% \mathrm{O}_{2}\right)$ for up to $48 \mathrm{~h}$. Cells were analyzed using FACS and Western blot. No significant changes, either in the number of apoptotic (annexin V-positive) cells or in the expression of proapoptotic proteins such as caspase-3 or -9 could be seen. These data are supported by publications demonstrating an increased resistance of placental cells to hypoxia-induced apoptosis (39). Other reports focus on the increasing numbers of apoptotic placental cells in the course of hypoxia $(40,41)$. Preeclampsia is a severe disorder of human pregnancy characterized by placental hypoxia and followed by activation of maternal endothelial cells as a final step. Hung et al. showed that reoxygenation after a state of hypoxia is the final key for the induction of apoptosis in syncytiotrophoblast cells whilst hypoxia alone is more likely to cause necrosis 
Control

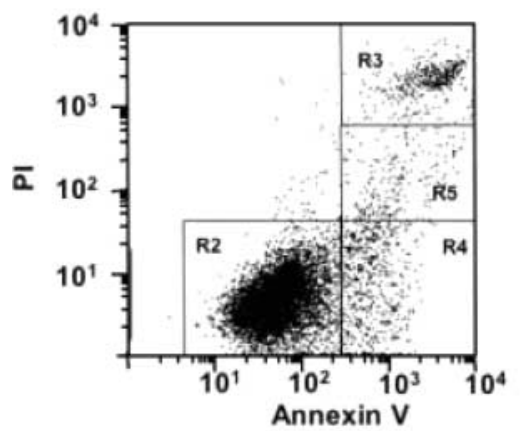

+ Hypoxia

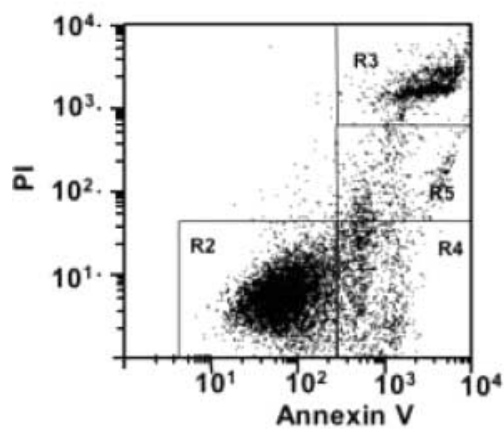

+Leptin
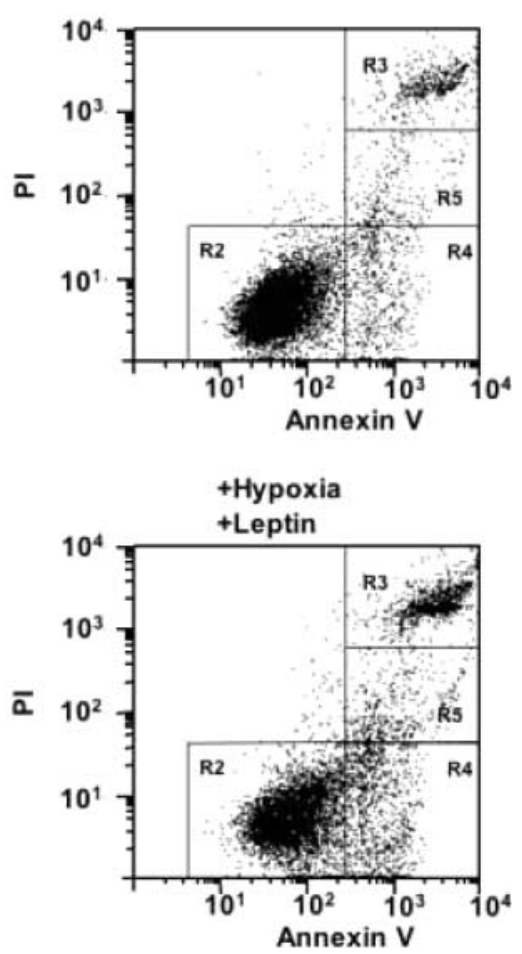

Figure 3 Flow cytometric analysis of apoptosis in JAr cells. Cells were stimulated for $48 \mathrm{~h}$ in the presence of $1 \mu \mathrm{g} / \mathrm{ml}$ leptin (+Leptin) or under hypoxic conditions $\left(1 \% \mathrm{O}_{2}\right.$, +

Hypoxia). In addition, hypoxic cells were stimulated using $1 \mu \mathrm{g} / \mathrm{ml}$ leptin (+ Leptin + Hypoxia). Afterwards, annexin V/propidium iodide $(\mathrm{PI})$ staining was used to determine early (annexin $\left.\mathrm{V}^{+} / \mathrm{PI}^{-}, \mathrm{R} 4\right)$ and late (annexin $\left.\mathrm{V}^{+} / \mathrm{PI}^{+}, \mathrm{R} 5\right)$ apoptotic cells. In addition, the viable cells (lower left quadrant of the cytogram, R2) and necrotic cells (upper right quadrant of the cytogram, R3) were counted.
(42). It still remains unclear what protected the JAr cells in our assays from undergoing apoptosis; also it is not known what caused the increased rate of apoptotic cell death in the reoxygenated cells. Leptin is thought to play a pivotal role in placental development and maintenance during pregnancy $(5,43)$. Comparing sera from women with preeclampsia with sera of mothers with uncomplicated pregnancies (44), elevated concentrations of this cytokine can be found in the

Table 1 Flow cytometric analysis of apoptosis in JAr cells. Cells were stimulated for 24 or $48 \mathrm{~h}$ in the presence of $1 \mu \mathrm{g} / \mathrm{ml}$ leptin (Leptin) or under hypoxic conditions $\left(1 \% \mathrm{O}_{2}\right.$, Hypoxia). In addition, hypoxic cells were stimulated using $1 \mu \mathrm{g} / \mathrm{ml}$ leptin $(\mathrm{L}+\mathrm{H})$. Annexin V/propidium iodide staining was used to determine early (EA) and late (LA) apoptotic cells. In addition, the viable (Living) and necrotic (Dead) cells were counted. The cells counted in the respective region (as depicted in Fig. 3) were divided by the absolute number of accepted cells. The numbers represent the mean \pm S.E.M. of 5 independent assays.

\begin{tabular}{lcccc}
\hline & Living & EA & LA & Dead \\
\hline 24h & & & & \\
Control & $87.1 \pm 2.6$ & $4.9 \pm 1.3$ & $2.8 \pm 0.9$ & $4.5 \pm 0.4$ \\
Leptin & $86.5 \pm 2.7$ & $4.9 \pm 1.4$ & $3.0 \pm 0.9$ & $5.0 \pm 0.6$ \\
Hypoxia & $79.0 \pm 2.6$ & $7.2 \pm 1.1$ & $4.1 \pm 0.6$ & $8.8 \pm 2.4$ \\
L+H & $80.3 \pm 3.1$ & $7.3 \pm 1.2$ & $3.7 \pm 0.8$ & $7.9 \pm 1.8$ \\
48 $\mathrm{h}$ & & & & \\
Control & $85.1 \pm 1.4$ & $4.5 \pm 0.9$ & $3.0 \pm 0.6$ & $6.7 \pm 0.8$ \\
Leptin & $84.9 \pm 1.4$ & $4.6 \pm 0.6$ & $3.2 \pm 0.6$ & $6.5 \pm 1.1$ \\
Hypoxia & $63.2 \pm 3.8 \S$ & $9.0 \pm 3.8 \S$ & $5.6 \pm 0.8 \S$ & $18.3 \pm 3.5 \S$ \\
L H & $65.8 \pm 3.4 \S$ & $10.4 \pm 1.8 \S$ & $5.5 \pm 0.6 \$$ & $16.6 \pm 2.6 \S$ \\
\hline
\end{tabular}

$\S P<0.05, \$ P<0.01$ compared with control (one-way ANOVA). preeclamptic mothers. This effect is mediated by the fact that leptin production could be enhanced by hypoxia $(20,21,26,29)$. Conflicting results have been found regarding the ability of the $o b$-gene product, leptin, to interfere with apoptosis $(11-13)$. We have chosen to administer quite high leptin concentrations, from $250 \mathrm{ng} / \mathrm{ml}$ up to $1.0 \mu \mathrm{g} / \mathrm{ml}$, because it has been shown in previous studies by Wolf and colleagues that a single dose of at least $500 \mu \mathrm{g} / \mathrm{ml}$ leptin $(\sim 30 \mathrm{nmol} / \mathrm{l})$ is necessary to induce a significant proliferation of mesangial cells in in vitro cultures (45). To our surprise, leptin added to

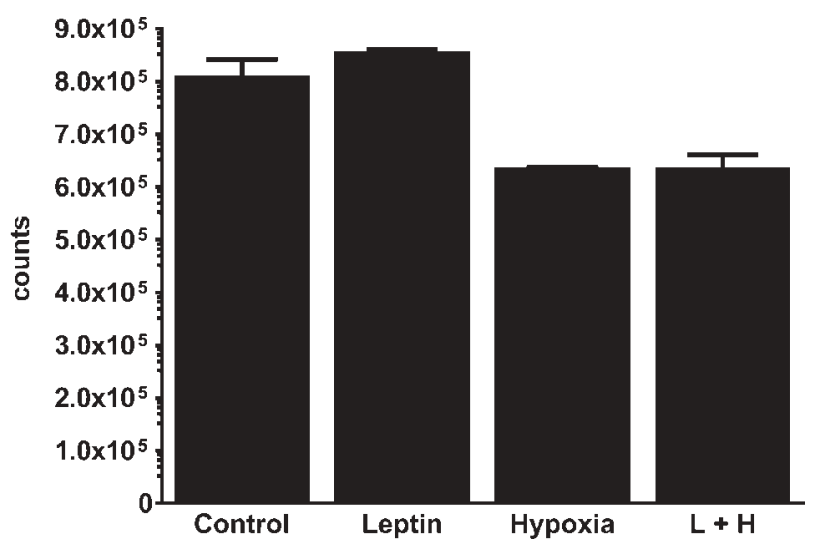

Figure 4 Cell counts of stimulated JAr cells. Cells were stimulated for $24 \mathrm{~h}$ in the presence of $1 \mu \mathrm{g} / \mathrm{ml}$ leptin (Leptin) or under hypoxic conditions ( $1 \% \mathrm{O}_{2}$, Hypoxia). In addition, hypoxic cells were stimulated using $1 \mu \mathrm{g} / \mathrm{ml}$ leptin $(\mathrm{L}+\mathrm{H})$. Afterwards, cells were counted by flow cytometry using beads. 


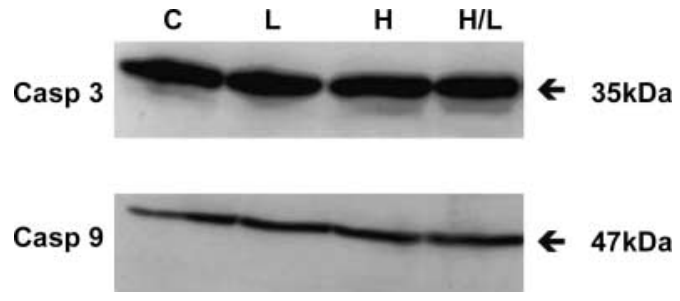

Figure 5 Equal expression of caspase-3 and caspase-9 in JAr cells after exposure to hypoxia in the presence or absence of leptin. Cells were stimulated for $48 \mathrm{~h}$ in the presence of $1 \mu \mathrm{g} / \mathrm{ml}$ leptin (L) or under hypoxic conditions $\left(1 \% \mathrm{O}_{2}, \mathrm{H}\right)$ or with a combination of both stimuli $(\mathrm{H} / \mathrm{L})$. Afterwards, cells were lysed and subjected to Western blot analysis for the expression of caspase-3 (Casp 3) and -9 (Casp 9). Lysates of untreated cells were used as controls (C).

the culture medium was unable to interfere either with the rate of proliferation of the trophoblasts or with their rate of apoptosis, although we could demonstrate the existence of both leptin receptor isoforms in both cell lines. Previous work from several authors has shown that an oxygen tension of at least $2 \%$ or lower is necessary to induce a sufficient (HIF-1 $\alpha$-dependent) response $(46,47)$. We tested oxygen tensions of $5 \%$ to $1 \%$. Here, a lower production of leptin in the culture supernatant could be found when incubating the cells with more oxygen. The exposure to 5\% oxygen had no effect on the survival of the cells or on leptin added to the cell culture (in comparison to normoxic controls, or the hypoxic cells kept at $1 \%$ oxygen tension). Another attribute of placenta cells is the secretion of $\beta$-hCG. When JAr cells were tested, no significant effect of leptin or short term $(24 \mathrm{~h})$ hypoxia on $\beta$-hCG concentration could be measured when analyzing the culture supernatants in an ELISA. After $48 \mathrm{~h}$, a decreased $\beta$-hCG concentration in the culture supernatants of the hypoxic cells was found. This has been observed before (48). Thus, leptin added to the hypoxic cells had no significant effect on the hypoxia-dependent reduction of hCG secretion (data not shown).

Our data suggest that placental leptin, induced by hypoxia, may exert functions in the placenta other than preventing the cells (e.g. trophoblasts) from undergoing (hypoxia driven) apoptosis. In addition, the hormone does not seem to play a role as an additional proliferative factor for placental cells during hypoxia. Thus, additional assays (e.g. in animal studies) are needed to discover the physiological role of leptin in the placenta during hypoxia.

\section{Acknowledgements}

This work was supported by the German Research Foundation to J D (DO682/3-2) and by the ELAN-Program of the University of Erlangen-Nürnberg to U M.

\section{References}

1 Ahima RS \& Flier JS. Leptin. Annual Review of Physiology 200062 413-437.

2 Dötsch J, Rascher W \& Meißner U. Perinatal programming of appetite control by leptin? European Journal of Endocrinology 2004151 159-160.

3 Fantuzzi G \& Faggioni R. Leptin in the regulation of immunity, inflammation, and hematopoiesis. Journal of Leukocyte Biology $200068437-446$.

4 Fruhbeck G. Peripheral actions of leptin and its involvement in disease. Nutr Rev 200260 S47-S55.

5 Henson MC \& Castracane VD. Leptin: roles and regulation in primate pregnancy. Seminars in Reproductive Medicine 200220 $113-122$.

6 Brunelle JK \& Chandel NS. Oxygen deprivation induced cell death: an update. Apoptosis 2002 7 475-482.

7 Levy R \& Nelson DM. To be, or not to be, that is the question. Apoptosis in human trophoblast. Placenta 200021 1-13.

8 DiFederico E, Genbacev O \& Fisher SJ. Preeclampsia is associated with widespread apoptosis of placental cytotrophoblasts within the uterine wall. American Journal of Pathology 1999155 293-301.

9 Genbacev O, DiFederico E, McMaster M \& Fisher SJ. Invasive cytotrophoblast apoptosis in preeclampsia. Human Reproduction 1999 14 (Suppl 2) 59-66.

10 Myatt L. Role of placenta in preeclampsia. Endocrine 200219 103-111.

11 Della-Fera MA, Qian H \& Baile CA. Adipocyte apoptosis in the regulation of body fat mass by leptin. Diabetes, Obesity and Metabolism 20013 299-310.

12 Fujita Y, Murakami M, Ogawa Y, Masuzaki H, Tanaka M, Ozaki S, Nakao K \& Mimori T. Leptin inhibits stress-induced apoptosis of T lymphocytes. Clinical and Experimental Immunology 2002128 $21-26$.

13 Russo VC, Metaxas S, Kobayashi K, Harris M \& Werther GA. Antiapoptotic effects of leptin in human neuroblastoma cells. Endocrinology 2004145 4103-4112.

14 Sivan E, Whittaker PG, Sinha D, Homko CJ, Lin M, Reece EA \& Boden G. Leptin in human pregnancy: the relationship with gestational hormones. American Journal of Obstetrics and Gynecology $19981791128-1132$.

15 Sagawa N, Yura S, Itoh H, Mise H, Kakui K, Korita D, Takemura M, Nuamah MA, Ogawa Y, Masuzaki H, Nakao K \& Fujii S. Role of leptin in pregnancy-a review. Placenta 200223 (Suppl A) S80-S86.

16 Ashworth CJ, Hoggard N, Thomas L, Mercer JG, Wallace JM \& Lea RG. Placental leptin. Reviews of Reproduction $2000 \mathbf{5}$ $18-24$.

17 Highman TJ, Friedman JE, Huston LP, Wong WW \& Catalano PM. Longitudinal changes in maternal serum leptin concentrations, body composition, and resting metabolic rate in pregnancy. American Journal of Obstetrics and Gynecology $1998 \mathbf{1 7 8}$ 1010-1015.

18 Ertl T, Funke S, Sarkany I, Szabo I, Rascher W, Blum WF \& Sulyok E. Postnatal changes of leptin levels in full-term and preterm neonates: their relation to intrauterine growth, gender and testosterone. Biology of the Neonate 199975 167-176.

19 Chardonnens D, Cameo P, Aubert ML, Pralong FP, Islami D, Campana A, Gaillard RC \& Bischof P. Modulation of human cytotrophoblastic leptin secretion by interleukin-1alpha and 17betaoestradiol and its effect on hCG secretion. Molecular and Human Reproduction 19995 1077-1082.

20 Grosfeld A, Turban S, Andre J, Cauzac M, Challier JC, Hauguel-de Mouzon S \& Guerre-Millo M. Transcriptional effect of hypoxia on placental leptin. FEBS Letters 2001502 122-126.

21 Meißner U, Östreicher I, Allabauer I, Rascher W \& Dötsch J. Synergistic effects of hypoxia and insulin are regulated by different transcriptional elements of the human leptin promoter. Biochemical and Biophysics Research Communications 2003303 707-712. 
22 Redman CW \& Sargent IL. The pathogenesis of pre-eclampsia. Gynecol Obstet Fertil $200129518-522$.

23 Tjoa ML, Oudejans CB, van Vugt JM, Blankenstein MA \& van Wijk IJ. Markers for presymptomatic prediction of preeclampsia and intrauterine growth restriction. Hypertension in Pregnancy $200423171-189$.

24 Lepercq J, Guerre-Millo M, Andre J, Cauzac M \& Hauguel-de Mouzon S. Leptin: a potential marker of placental insufficiency. Gynecologic and Obstetric Investigation 200355 151-155.

25 Dötsch J, Nusken KD, Knerr I, Kirschbaum M, Repp R \& Rascher W. Leptin and neuropeptide $\mathrm{Y}$ gene expression in human placenta: ontogeny and evidence for similarities to hypothalamic regulation. Journal of Clinical Endocrinology and Metabolism $1999842755-2758$.

26 Meißner U, Hänisch C, Östreicher I, Knerr I, Hofbauer KH, Blum WF, Allabauer I, Rascher W \& Dötsch J. Differential regulation of leptin synthesis in rats during short-term hypoxia and short-term carbon monoxide inhalation. Endocrinology 2005 $146215-220$.

27 Meißner U, Allabauer I, Repp R, Rascher W \& Dötsch J. Inducible expression of hypoxia-inducible factor 1alpha (HIF-1alpha) as a tool for studying HIF-1alpha-dependent gene regulation during normoxia in vitro. Pharmacology $20036974-78$.

28 Guerre-Millo M, Grosfeld A \& Issad T. Leptin is a hypoxia-inducible gene. Obesity Research 200210856 author reply 857-858.

29 Grosfeld A, Andre J, Hauguel-De Mouzon S, Berra E, Pouyssegur J \& Guerre-Millo M. Hypoxia-inducible factor 1 transactivates the human leptin gene promoter. Journal of Biological Chemistry $200227742953-42957$.

30 Wang J, Liu R, Hawkins M, Barzilai N \& Rossetti L. A nutrient-sensing pathway regulates leptin gene expression in muscle and fat. Nature $1998393684-688$.

31 Purdham DM, Zou MX, Rajapurohitam V \& Karmazyn M. Rat heart is a site of leptin production and action. American Journal of Physiology. Heart and Circulation Physiology $2004 \quad \mathbf{2 8 7}$ $\mathrm{H} 2877-\mathrm{H} 2884$.

32 Bado A, Levasseur S, Attoub S, Kermorgant S, Laigneau JP, Bortoluzzi MN, Moizo L, Lehy T, Guerre-Millo M, Le MarchandBrustel Y \& Lewin MJ. The stomach is a source of leptin. Nature $1998394790-793$.

33 Bifulco G, Trencia A, Caruso M, Tommaselli GA, Miele C, di Carlo C, Beguinot F \& Nappi C. Leptin induces mitogenic effect on human choriocarcinoma cell line (JAr) via MAP kinase activation in a glucose-dependent fashion. Placenta 200324 385-391.

34 Kingdom JC \& Kaufmann P. Oxygen and placental vascular development. Advances in Experimental Medicine and Biology $1999 \mathbf{4 7 4} 259-275$.

35 Morrish DW, Dakour J \& Li H. Life and death in the placenta: new peptides and genes regulating human syncytiotrophoblast and extravillous cytotrophoblast lineage formation and renewal. Current Protein and Peptide Science 20012 245-259.
36 Caniggia I, Mostachfi H, Winter J, Gassmann M, Lye SJ, Kuliszewski M \& Post M. Hypoxia-inducible factor-1 mediates the biological effects of oxygen on human trophoblast differentiation through TGFbeta(3). Journal of Clinical Investigation 2000 $105577-587$.

37 Challier JC \& Uzan S. The human placenta and its pathologies: focus on oxygen. Médicine Sciences $2003191111-1120$.

38 Esterman A, Greco MA, Mitani Y, Finlay TH, Ismail-Beigi F \& Dancis J. The effect of hypoxia on human trophoblast in culture: morphology, glucose transport and metabolism. Placenta 199718 129-136.

39 Kilani RT, Mackova M, Davidge ST \& Guilbert LJ. Effect of oxygen levels in villous trophoblast apoptosis. Placenta $2003 \mathbf{2 4}$ 826-834.

40 Levy R, Smith SD, Chandler K, Sadovsky Y \& Nelson DM. Apoptosis in human cultured trophoblasts is enhanced by hypoxia and diminished by epidermal growth factor. American Journal of Physiology. Cell Physiology 2000278 C982-C988.

41 Gude NM, Stevenson JL, Moses EK \& King RG. Magnesium regulates hypoxia-stimulated apoptosis in the human placenta. Clinical Science $200098375-380$.

42 Hung TH, Skepper JN, Charnock-Jones DS \& Burton GJ. Hypoxiareoxygenation: a potent inducer of apoptotic changes in the human placenta and possible etiological factor in preeclampsia. Circulation Research $2002901274-1281$.

43 Holness MJ, Munns MJ \& Sugden MC. Current concepts concerning the role of leptin in reproductive function. Molecular and Cellular Endocrinology 1999157 11-20.

44 Poston L. Leptin and preeclampsia. Seminars in Reproductive Medicine $200220131-138$.

45 Wolf G, Hamann A, Han DC, Helmchen U, Thaisss F, Ziyadeh FN \& Stahl RAK. Leptin stimulates proliferation and TGF-beta expression in renal glomerular endothelial cells: potential role in glomerulosclerosis. Kidney International 199956 860-872.

46 Rajakumar A \& Conrad KP. Expression, ontogeny, and regulation of hypoxia-inducible transcription factors in the human placenta. Biology of Reproduction $200063559-569$.

47 Seligman SP, Nishiwaki T, Kadner SS, Dancis J \& Finlay TH. Hypoxia stimulates ecNOS mRNA expression by differentiated human trophoblasts. Annals of the New York Academy of Sciences $1997828180-187$.

48 Strohmer H, Kiss H, Mosl B, Egarter C, Husslein P \& Knofler M. Hypoxia downregulates continuous and interleukin-1-induced expression of human chorionic gonadotropin in choriocarcinoma cells. Placenta $1997 \mathbf{1 8} 597-604$.

Received 22 February 2005

Accepted 1 June 2005 